\title{
Squamata, Scincidae, Mabuya dorsivittata (Cope, 1862): Distribution extension in Buenos Aires province, Argentina
}

\author{
Jorge Williams* and Federico Kacoliris
}

\begin{abstract}
Universidad Nacional de La Plata, Facultad de Ciencias Naturales y Museo de La Plata, División Zoología de Vertebrados, Sección Herpetología. Paseo del Bosque s/n. CP1900, La Plata, Buenos Aires, Argentina.
\end{abstract}

* Corresponding author. E-mail: williams@museo.fcnym.unlp.edu.ar

\begin{abstract}
Mabuya dorsivttata is a lizard with a wide distribution in South America. In Buenos Aires province, Argentina, previous voucher records exist only from its northern sector and from Mar del Plata city. In this work, two new records of $M$. dorsivittata from Buenos Aires province are presented: (1) Azul city ( $36^{\circ} 46^{\prime} 50^{\prime \prime}$ S, 50 51'10" W) and (2) Mar del Tuyú city $\left(37^{\circ} 20^{\prime} 08^{\prime \prime} \mathrm{S}, 5^{\circ} 07^{\prime} 60^{\prime \prime} \mathrm{W}\right)$. These new records are located about $175 \mathrm{~km}$ from the nearest previous record.
\end{abstract}

Mabuya dorsivttata is a generalist lizard that uses a wide variety of habitats, like grasslands, forest, and rocky surfaces (Gallardo 1968; Cei 1993), besides some observations of aquatic habits (Gudynas 1980).

The known distribution of this lizard includes a great portion of Argentina, Bolivia (up to Santa Cruz de la Sierra), southeastern Brasil and Uruguay (Gallardo 1968; Cei 1993). In Argentina, the distribution range includes the provinces of Salta, Chaco, Formosa, Tucumán, Catamarca, Santiago del Estero, Córdoba, Santa Fé, a great part of Mendoza, Misiones, Corrientes, Entre Ríos and Buenos Aires (Cei 1993). In Buenos Aires, there are confirmed records (with voucher specimens) only for the northern sector of the province and from Mar del Plata city (Liebermann 1939).

In the present work, two new confirmed records are presented for $M$. dorsivittata. Voucher specimens are deposited in the herpetological section of the Museo de La Plata, Buenos Aires, Argentina. The first record (MLP.R.5366) from Azul city (3646'50” S, 5051'10” W), at the center of the Buenos Aires Province, and the second

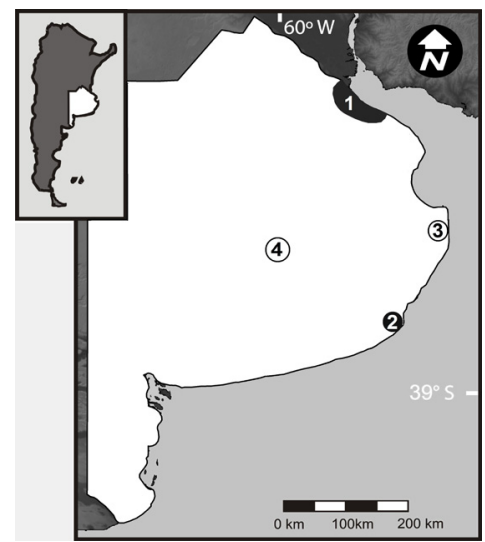

FIGURE 1. Records of Mabuya dorsivittata in Buenos Aires province. North of Buenos Aires (1) and Mar del Plata city (2) represent the previous records, whereas Mar del Tuyu city (3) and Azul city (4) are the new records.
(MLP.R.5465) from Mar del Tuyú coastal city (37²0’08" $\left.\mathrm{S}, 59^{\circ} 07^{\prime} 60^{\prime \prime} \mathrm{W}\right)$. The new records are approximately 260 $\mathrm{km}$ (Azul) and $280 \mathrm{~km}$ (Mar del Tuyú) S from previous records in the north of Buenos Aires province, and $175 \mathrm{~km}$ (Azul) and $240 \mathrm{~km}$ (Mar del Tuyú) from Mar del Plata city (Figure 1). The new records come from different habitats, being Azul sector dominated by high pampas grasslands and Mar del Tuyú, a coastal dunal area dominated by low to medium grasslands. Cei (1993) suggests an irregular distribution for this lizard, though more surveys are necessary to confirm whether that irregularity is related with the species distribution or with the absence of extensive surveys at intermediate localities. It is also possible that these records could be related with human process of species dispersion, as it was described for this lizard in San Juan Province (Gómez and Acosta 1998).

Acknowledgments: Club de Ciencias de la Costa and Departamento de Zoonosis Rurales de Azul (Ministerio de Salud de la Provincia de Buenos Aires) gave voucher specimens for this work. JW and FK salaries were extended by Consejo Nacional de Investigaciones Científicas y Técnicas. Camila Cass made valuable suggestion on the manuscript.

\section{LITERATURE CITED}

Gallardo, J.M. 1968. Las especies argentinas del género Mabuya Fitzinger. Revista del Museo Argentino de Ciencias Naturales, Zoología 9: 177196.

Cei, J.M. 1993. Reptiles del Noroeste, Nordeste y Este de la Argentina. Herpetofauna de las selvas subtropicales, puna y pampas. Torino: Museo Regionali di Scienze Naturali (Monografie 14). 950 p.

Gómez, P.F. and J.C. Acosta. 1998. Introducción accidental de reptiles y anfibios en el departamento de Caucete, San Juan, Argentina. Multequina 7: 73-75.

Gudynas, E. 1980. Notas adicionales sobre la distribución, ecología y comportamiento de Mabuya dorsivittata. Contribuciones en Biología C.E. Don Orione 2: 1-13.

Liebermann,J.1939. Catálogo sistemático y bibliográfico de los Lacertilios argentinos. Physis 16: 61-82.

RECEIVED: April 2010

LAST REVISED: June 2011

ACCEPTED: June 2011

Published ONLINE: June 2011

EDITORIAL RESPONSIBILITY: Renato S. Bérnils 